\title{
Three forms of gonadotropin-releasing hormone (GnRH) in brain and pituitary of Asian seabass Lates calcarifer (Bloch, 1790) analysed by high performance liquid chromatography combined with time-resolved flouroimmunoassay and immunohistochemistry
}

\author{
KY XUAN PHAM, MASAFUMI AMANO*, NORIKO AMIYA*, HA VIET DAO \\ AND QUANG VAN VO \\ Institute of Oceanography, Vietnam Academy of Science and Technology, Cau Da - 01, Nha Trang \\ Khanh Hoa, Vietnam \\ *School of Marine Biosciences, Kitasato University, Sagamihara, Kanagawa - 252 0373, Japan \\ e-mail: phamkx@vnio.org.vn
}

\begin{abstract}
Three forms of gonadotropin-releasing hormone (GnRH) namely, salmon GnRH (sGnRH), chicken GnRH-II (cGnRH-II) and seabream GnRH (sbGnRH) were identified in the brain of Asian seabass Lates calcarifer using reverse-phase high performance liquid chromatography (rpHPLC) combined with time-resolved fluoroimmunoassay (TR-FIA) using rabbit polyclonal antibody raised against sGnRH, cGnRH-II and sbGnRH. An extract of L. calcarifer brain showed a similar retention time to that of synthetic sGnRH, cGnRH-II and sbGnRH on rpHPLC. In the brain, cGnRH-II and sGnRH levels were high, whereas sbGnRH was absolutely dominant in the pituitary. In addition, cGnRH-II, sGnRH and sbGnRH-immunoreactive (ir) cell bodies and fibers in the brain and pituitary were also examined by immunohistochemistry. sGnRH-ir cell bodies were localised in the ventromedial part of the rostral olfactory bulb, terminal nerve ganglion region, and the transitional area between the olfactory bulb and telencephalon. cGnRH-II-ir cell bodies were located only in the midbrain tegmentum and sbGnRH-ir cell bodies were evident in the preoptic area. sGnRH-ir fibers were distributed throughout the brain, especially abundant in the forebrain. cGnRH-II-ir fibers were found in many parts of the brain, being more dense in the midbrain, whereas sbGnRH-ir fibers were localised in the preoptic-hypothalamic area, innervating the pituitary. In the pituitary, sbGnRH-ir fibers were profuse in the neurohypophysis and invaded the proximal pars distalis. These results confirm the existence of multiple GnRH forms with different physiological roles in L. calcarifer. Among them, sbGnRH is considered to be the best candidate for pituitary regulation while sGnRH and cGnRH-II can function as neurotransmtters or as neuromodulators in this species.
\end{abstract}

Keywords: Brain, Flouroimmunoassay, GnRH, HPLC, Immunohistochemistry, Lates calcarifer, Pituitary

\section{Introduction}

Gonadotropin-releasing hormone $(\mathrm{GnRH})$ is a decapeptide regulating several physiological functions in vertebrates (Amano et al., 1997; Okuzawa and Kobayashi, 1999; Lethimonier et al., 2004). GnRH was first isolated from mammals (Matsuo et al., 1971) and later from tetrapods (King and Millar, 1979) and teleosts (Sherwood et al., 1983). Till date, eight GnRH forms have been identified in teleosts and two or three GnRHs were found in a single species. Recent reports on GnRH forms confirmed that two common forms are chicken GnRH-II (cGnRH-II) and salmon GnRH (sGnRH). There is also a third form reported as seabream GnRH (sbGnRH), herring GnRH (hrGnRH), medaka GnRH (mdGnRH), pejerrey $\mathrm{GnRH}$ (pjGnRH) and whitefish GnRH (wfGnRH) in fishes (Lethimonier et al., 2004). The GnRH forms were named following the species in which they were first isolated, except for the mammalian GnRH (mGnRH) (Sherwood et al., 1983; Yu et al., 1988; Bogerd et al., 1992; Powell et al., 1994; Carolsfeld et al., 2000; Montaner et al., 2001; Adams et al., 2002). Among GnRHs, cGnRH-II is the ubiquitous form present in all teleosts and possibly the most ancient form of GnRH. The second GnRH is a species-specific form (Powell et al., 1994), while the third form represents advanced evolutionary teleosts. The latter forms of GnRH may have arisen as a result of nucleotide substitutions in the gene of ancient form.

Each GnRH is distinguished from others by difference in positions of amino acid residues among ten amino acids in the chemical structure. It is generally accepted that $\mathrm{GnRH}$ in the brain of teleosts is involved in reproduction via stimulating pituitary gonadotropins 
through GnRH receptors (Lethimonier et al., 2004). In addition, GnRH can also induce release of other pituitary hormones, including growth hormone (Marchant et al., 1989) and prolactin (Weber et al., 1997). However, studies on the function of each GnRH in the brain of teleosts is complicated due to the presence of multiple GnRH forms. It is suggested that GnRHs can express different functions such as neuromodulation/neurotransmission or act as local hormones in teleosts according to their location in the brain (Kah et al., 2007). More recently, it has been revealed that GnRHs can also modulate auditory processing in the fish brain (Maruska and Tricas, 2011) or function as olfactory and visual neuromodulators (Servili et al., 2012).

Immunological, molecular and chromatographic analyses showed that the order Perciformes, the largest group of teleosts, with representatives such as the gilthead seabream Sparus aurata (Gothilf et al., 1996), whitefish Coregonus clupeaformis (Adams et al., 2002), European seabass Dicentrarchus labrax (Gonzalez-Martinez et al., 2002), barfin flounder Verasper moseri (Amano et al., 2002), Japanese flounder Paralichthys olivaceus (Pham et al., 2007) and chub mackerel Scomber japonicus (Selvaraj et al., 2009) express three GnRH forms in the brain. Among them, cGnRH-II, with the population of unique GnRH cells in the midbrain and wide distribution of fibers in different regions of the brain, is proposed to play a role in neuromodulation. sGnRH usually act as a neuromodulator and/or neurotransmitter (Soga et al., 2005). cGnRH-II and sGnRH are considered to be non-hypophysiotropic forms and their physiological roles remained unclear in teleosts possessing three GnRHs. The third GnRH form, with distribution in the neuronal population of the preoptic area (POA) as well as hypothalamus and innervation of fibers into the anterior pituitary though hypothalamus is the hypophysiotropic form regulating reproduction in teleosts by stimulating gonadotropin release (Lethimonier et al., 2004).

Lates calcarifer, a carnivorous fish, is distributed in the tropical and sub-tropical areas of the Western Pacific and Indian Ocean (Phillips, 1998). This fish is a highly commercial species and is important for aquaculture in several Asian countries. L. calcarifer is a diadromous fish exhibiting complex sexuality making it an interesting specimen for academic studies (Moore, 1979). Under natural condition, fish spend most its life in river mouths, lakes or lagoons and spawning event occurs in brackishwater estuaries (Rimmer and Russell, 1998). Under captive condition, gonadal maturation in mature fish can be induced by pellet implantation of luteinising hormone-releasing hormone analogue [(D-Ala ${ }^{6}$; Pro $\left.^{9}-\mathrm{NEt}\right)$ LHRH], [D-Ala ${ }^{6}$; Pro'-ethylamide] $\mathrm{mGnRH}$ and [D-Arg ${ }^{6}$; Pro'-ethylamide] sGnRH and 17 $\alpha$-methyltestosterone.
Spawning in mature female could be stimulated by injection of LHRH and GnRH-analogues and the fish can spawn repeatedly in batches for several days (Almendras et al., 1988; Garcia, 1989). However, endocrine profile and mechanism of hormones regulating reproduction have not been fully studied in this species. Until now, only preprocGnRH-II precursor sequences in the brain of this species have been identified and analysed (Tan et al., 2008). To better understand the possible role and physiological relevance of hormones in L. calcarifer, we analysed GnRH forms, the anatomical localisation and distribution of these hormones in the brain and pituitary in this species.

\section{Materials and methods}

Fish sampling

Wild L. calcarifer were caught in Nha Phu Lagoon, Khanh Hoa Province, Vietnam employing gillnet or fish hook with baits. Live fishes were kept in a floating net cage in the sea for 1-2 days. The fish were then transported to Oceanography Institute, Nha Trang, Vietnam with oxygen supplementation within $1 \mathrm{~h}$. The fishes were anesthetised by immersion in ice water. Total length (TL) and body weight $(\mathrm{BW})$ were measured, ovaries were removed and weighed to calculate gonadosomatic index (GSI). The fish were treated in accordance with the guidelines stipulated by the world society for the protection of animals in Vietnam.

\section{Tissue preparation}

For high performance liquid chromatography (HPLC) and time-resolved flouroimmunoassay (TR-FIA) analyses, the brains and pituitaries were removed quickly from the decapitated fish and placed on dry ice. The samples were then stored at $-80^{\circ} \mathrm{C}$ until $\mathrm{GnRH}$ peptide extraction. Deeply frozen brain tissues in dry ice were air lifted to Japan and analyses were carried out in Kitasato University. The TL, BW and GSI of the five individuals used for this experiment were $40.1-50.2 \mathrm{~cm}, 3.5-4.7 \mathrm{~kg}$ and $2.4-3.50 \%$ respectively.

For immunohistochemical analysis, chondrocranium including brain were fixed in Bouin's solution at $4^{\circ} \mathrm{C}$ for $24 \mathrm{~h}$. The TL, BW and GSI of the individuals used for the experiment were $50.2-115 \mathrm{~cm}, 5.0-16.74 \mathrm{~kg}$ and $2.70-11.15 \%$ respectively.

Reverse-phase HPLC separation and TR-FIA detection of GnRH

GnRH peptides from frozen brains and pituitaries were extracted as per the method described by Okuzawa et al. (1993) with slight modification. The extracts after removing lipids with petroleum ether were 
passed through a $0.22 \mu \mathrm{m}$ filter (Millipore Corp, Bedford, MA). The filtered GnRH extracts were separated by reverse phase (rp) HPLC to separate GnRH forms as described by Amano et al. (2009). In brief, the filtrates $(800-900 \mu \mathrm{l})$ were injected through a $1 \mathrm{ml}$ injection loop onto an ODS-120T (0.46 x $25 \mathrm{~cm}$, Tosoh, Tokyo, Japan). Liquid chromatography was programmed at a flow of $1 \mathrm{ml}$ per min in a high-pressure gradient system with two pumps (980-PU, JASCO, Tokyo, Japan) which used acetonitrile containing $0.1 \%$ trifluoroaceticacid (TFA). The percentage of acetonitrile was increased linearly from $10 \%$ (0 min) to $50 \%$ (50 min). Fractions were collected every $30 \mathrm{sec}$ from the $18^{\text {th }}$ to $36^{\text {th }} \mathrm{min}$. A standard solution containing $1 \mu \mathrm{g}$ each of cGnRH-II, lamprey (1) GnRH-II, octopus (oct) GnRH, sGnRH and sbGnRH in $200 \mu \mathrm{l}$ of $0.1 \%$ TFA was also injected and fractionated as explained above. All fractions collected from the samples and standard were freeze-dried in a vacuum centrifuge concentrator. Dried residues were dissolved in $500 \mu \mathrm{l}$ of TR-FIA assay buffer $(20 \mathrm{mM}$ sodium phosphate buffer, $0.9 \% \mathrm{NaCl}, 0.1 \% \mathrm{BSA}, 20 \mu \mathrm{M}$ diethylenetriamine-N,N, $\mathrm{N}^{\prime}, \mathrm{N}^{\prime \prime}, \mathrm{N}^{\prime \prime}$-pentaacetic acid, $0.01 \%$ Tween-40; pH 7.2) and were checked for cGnRH-II, sGnRH and sbGnRH by TR-FIA according to Amano et al. (2002). Antibodies to sGnRH (lot 2), cGnRH-II (acII 6), and sbGnRH (AS-691) were used in these assays.

\section{Immunohistochemistry for GnRHs}

The whole brains in Bouin's solution were removed from the chondrocranium and post-fixed in the same fluid at $4{ }^{\circ} \mathrm{C}$ for $12-24 \mathrm{~h}$. The tissues then were rinsed in cold $70 \%$ ethanol, subsequently dehydrated through a graded series of ethanol concentrations up to $100 \%$ and finally embedded in paraplast. Saggital sections at a thickness of $10 \mu \mathrm{m}$ were cut and mounted on aminopropyltriethoxysilane (APS) coated slides (Matsunami, Osaka, Japan). Immunohistochemistry for GnRHs was performed according to Amano et al. (2002) and Pham et al. (2007). The immunohistochemical reaction used was based on a streptavidin-biotin-peroxidase complex method using a Histofine immunostaining kit (Nichirei, Tokyo, Japan).

In these experiments, antibodies to sGnRH, cGnRH-II and sbGnRH were diluted into 2000-fold, 500 -fold and 10000-fold, respectively, in $0.1 \mathrm{M}$ phosphate buffer ( $\mathrm{pH} 7.4$ ) containing $0.75 \% \mathrm{NaCl}$ and $0.3 \%$ Triton $\mathrm{X}-100$ (PBST). The specificity of the immunoreactions was tested with pre-absorbed antibodies with the corresponding synthetic peptides of GnRH and the possibility of non-specific immunoreactions was also checked using the pre-absorbed antibodies with the non-corresponding synthetic peptides in the adjacent sections as described by Pham et al. (2007).

\section{Histology}

Histology of nuclear boundaries was identified in the adjacent sections stained with cresyl violet. The terminology for brain nuclei was according to Stefano et al. (2000) and Soga et al. (2005). All stained sections were examined under a microscope and digitally photographed. Figures of brain sections describing the distribution of GnRH-ir cell bodies and fibers were drawn using a camera lucida.

\section{Results and discussion}

\section{HPLC and TR-FIA analysis}

In the brain extract of the fish, three chromatographic and immunological peptides corresponding to fractions 32, 26 and 23 were identical to sGnRH (Fig. 1a), cGnRH-II (Fig. 1b) and sbGnRH (Fig. 1c) respectively. Retention time of each GnRH-ir form was similar to the elution positions of the synthetic sGnRH, cGnRH-II and sbGnRH standards. The extract from pituitaries of seabass showed dominance of sbGnRH, corresponding to the fractions 23 and 24 (Fig. 1d).

The presence of multiple $\mathrm{GnRH}$ forms (sGnRH, cGnRH-II, and sbGnRH) in L. calcarifer brain was confirmed in the present study as reported in a number of modern teleosts (Powell et al., 1994; Senthilkumaran et al., 1999; Montaner et al., 2001; Amano et al., 2002; Pham et al., 2007; Selvaraj et al., 2009). The results also revealed that sbGnRH was the dominant form in the pituitary of $L$. calcarifer. This study, together with the above-mentioned reports, confirmed that the third GnRH form in the brain of most perciform fish was sbGnRH. The data obtained from the present work showed three populations of GnRH-ir cell bodies expressed in distinct regions of $L$. calcarifer brain: sGnRH in the anterior brain, sbGnRH in the POA and cGnRH-II in the midbrain. Localisations of sGnRH and sbGnRH-ir cell bodies were differential in the forebrain of L. calcarifer. Distribution of GnRH-ir cell bodies in L. calcarifer brain was similar to D. labrax (Gonzalez-Martinez et al., 2002) and S. japonicus (Selvaraj et al., 2009), which possessed sGnRH, cGnRH-II, and sbGnRH.

Immunohistochemical localisation of $\mathrm{S} G \mathrm{RH} H$-ir cell bodies and fibers

The schematic illustration of sGnRH-ir cell bodies and fibers is summarised in Fig. 2(a-c). sGnRH-ir cell bodies were located along the ventral medial part of the rostral olfactory bulb (OB), the terminal nerve ganglion (TNG)- the transitional area between the olfactory bulb and telencephalon (Fig. $3 \mathrm{a}-\mathrm{d}$ ). These cell bodies were strongly immunostained and were clearly visible. sGnRH-ir fibers 


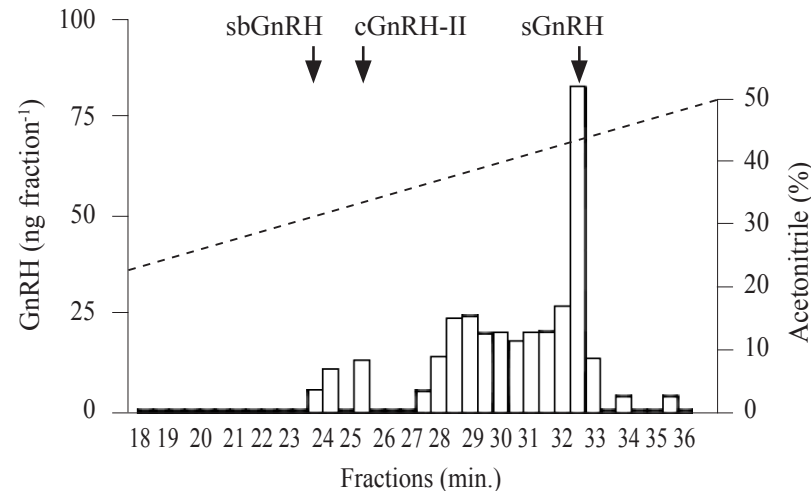

(a)

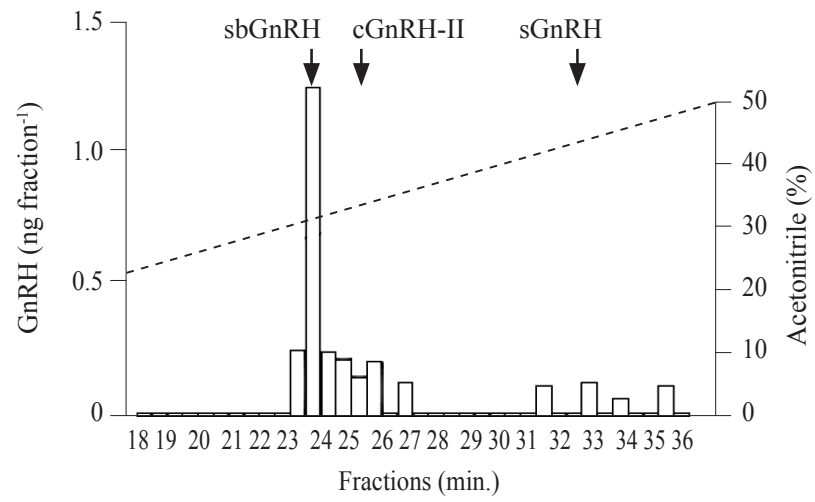

(c)

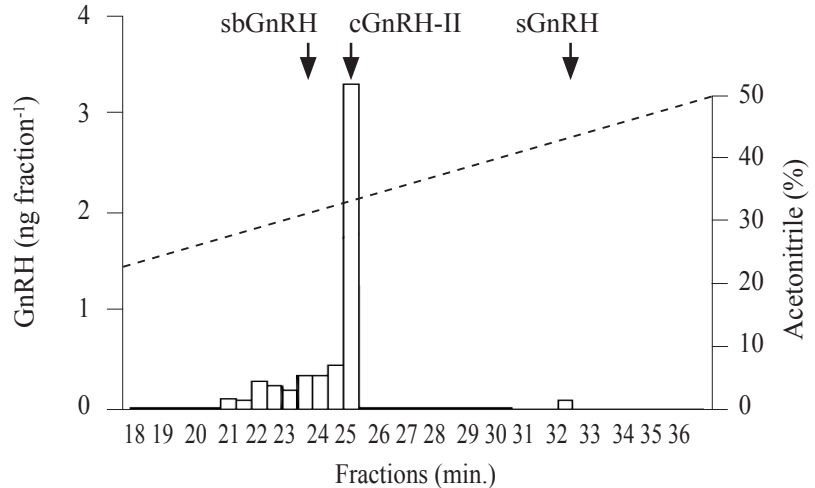

(b)

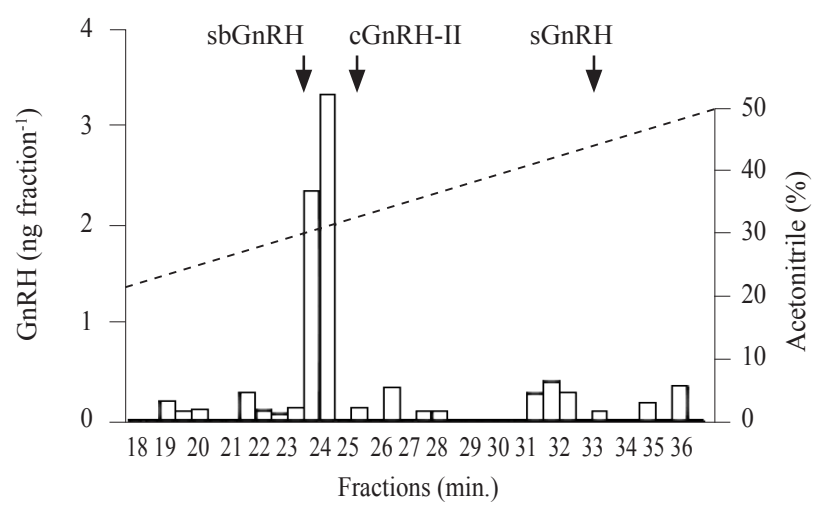

(d)

Fig. 1. Reverse-phase HPLC of GnRH immunoreactivity in the brain and pituitary extracts of $L$. calcarifer. Chromatograms show the elution position (minutes) and concentration of immunoreactive GnRH material (ng fraction ${ }^{-1}$ ) detected by specific antisera to three GnRH forms. Arrows at the top of each chromatogram indicate the elution positions of synthetic GnRH standards. (a) Immunoreactive GnRH in the brain detected by sGnRH antiserum, (b) Immunoreactive GnRH in the brain detected by cGnRH-II antiserum, (c) Immunoreactive GnRH in the brain detected by sbGnRH antiserum, (d) Immunoreactive GnRH in the pituitary detected by sbGnRH antiserum. The dotted lines represent percentage of $\mathrm{CH}_{3} \mathrm{CN}$ (acetonitrile) containing $0.1 \%$ trifluoroacetic acid in the mobile phase

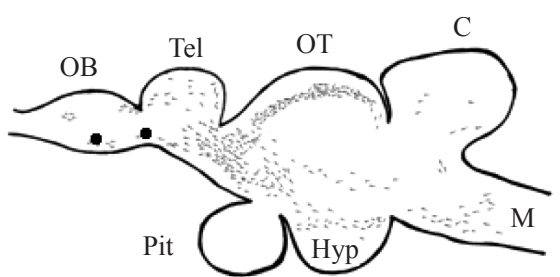

(a)

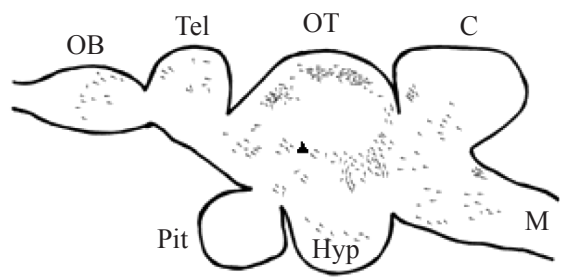

(b)

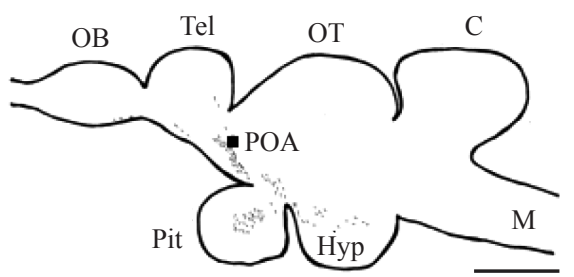

(c)

Fig. 2. Camera lucida drawing of the distribution of cell bodies (closed circles) and fibers (lines) in sagittal section for: (a) sGnRH-ir, (b) cGnRH-II-ir, (c) sbGnRH-ir. C: Cerebellum, Hyp: hypothalamus, M: medulla oblongata, MT: midbrain tegmentum, OB: olfactory bulb, OT: optic tectum, Pit: pituitary, POA: preoptic area, Tel: telencephalon, TNG: terminal nerve ganglion. Bars $=1 \mathrm{~mm}$.

were distributed throughout the brain and were concentrated mainly in the anterior part of the brain. They were evident in the OB, telencephalon, POA and hypothalamus (Fig. 2a, $3 \mathrm{c})$. In addition, long sGnRH-ir fibers were observed in the anterior POA, running caudal to the thalamus and hypothalamus with no clear destination (Fig. 3d). In the posterior brain, some sGnRH-ir fibers in the medulla oblongata and few in the cerebellum were observed.
Wide distribution of sGnRH-ir fibers in the brain suggested that $\mathrm{sGnRH}$ can function as a neuromodulator and/or neurotransmitter in L. calcarifer as presumed in several teleosts. However, the role of sGnRH is complicated and may be different among fish class. In fish with two $\mathrm{GnRH}$ forms, i.e., sGnRH and cGnRH-II, besides being a neuromodulator, sGnRH also acts as a regulator of pituitary gonadotropin secretion (Amano et al., 1991; 


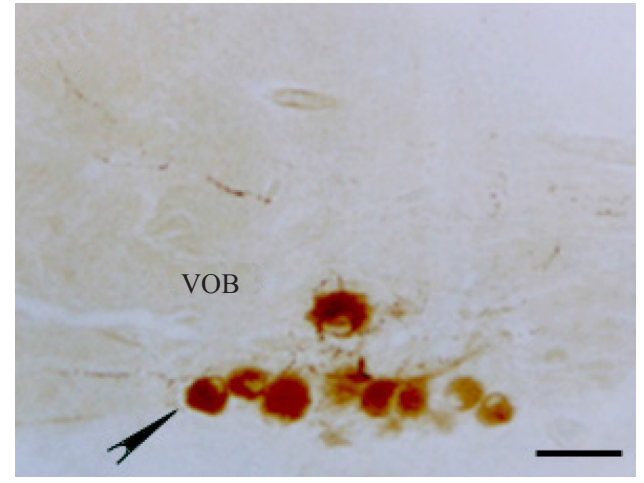

(a)

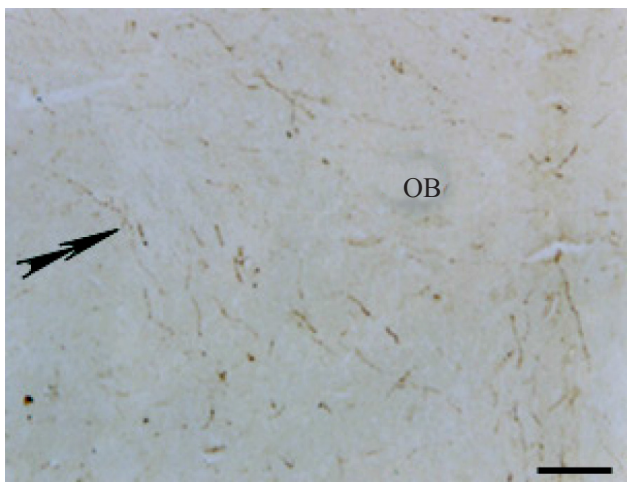

(c)

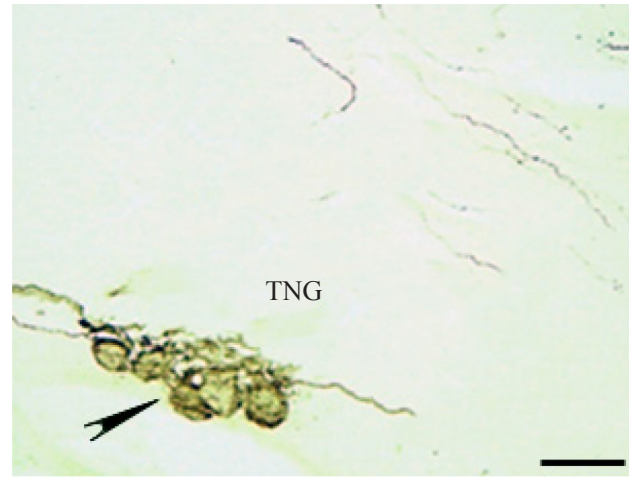

(b)

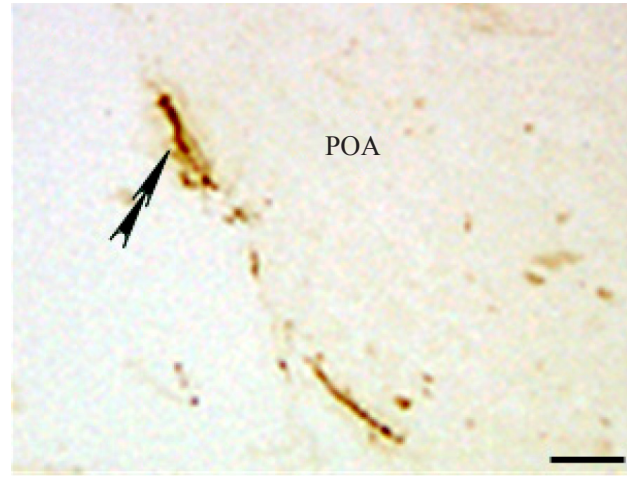

(d)

Fig. 3. Distribution of sGnRH-ir cell bodies (arrowheads) and fibers (double arrowheads) in sagittal sections. (a) sGnRH-ir cell bodies in the ventral olfactory bulb (VOB), (b) sGnRH-ir cell bodies in the TNG, (c) sGnRH-ir fibers in the OB and (d) sGnRH-ir fibers running parallel in the POA. Bars, $100 \mu \mathrm{m}$

Kim et al., 1995) and other pituitary hormones (Marchant et al., 1989; Weber et al., 1997). For fishes with three different GnRH forms, especially multiple-spawners, the physiological functions of sGnRH have still been obscure. Similar to V. moseri, P. olivaceus and D. labrax, a certain $\mathrm{sGnRH}$ amount detected in the pituitary of L. calcarifer revealed the possible role of this hormone in regulating pituitary function in this species. In addition dense sGnRH-ir fibers in the anterior brain of $L$. calcarifer suggested that these fibers might have originated from the $\mathrm{TN}$ ir-cell population in the forebrain as found in other teleosts (Oka and Matshishima, 1993; Yamamoto et al., 1995). It was found that sGnRH from the TN appears to serve complex functions such as regulating sexual behaviour in the goldfish Carassius auratus (Kobayashi et al., 1994), controlling nest-building initiation in the dwarf gourami Colisa lalia (Yamamoto et al., 1997) or coordinating sensory, motivational and visual system in the African cichlid Haplochromis burtoni (White et al., 1995). Recently, it has also been shown that in D. labrax, retinopetal projection in the $\mathrm{TN}$ area suggests that TN-GnRH modulates dopaminergic cell activities and retinal function (Servili et al., 2012). Moreover, the occurrence of the parallel sGnRH-ir fibers and
sbGnRH-ir fibers in the POA without entering the pituitary area is similar to that reported in S. japonicus (Selvaraj et al., 2009). In D. labrax (Gonzalez-Martinez et al., 2001) and Atlantic croaker Micropogonias undulates (Mohamed et al., 2005), overlapping of sGnRH and sbGnRH mRNA expression patterns in the ventral telencephalon and POA has also been reported. Thus, it is necessary to investigate GnRH mRNA expression by using in situ hybridisation and GnRH receptor expression in GnRH neurons for clarifying the overlapping of $\mathrm{sGnRH}$ and sbGnRH-ir fibers in the POA in order to better understand the activity of these hormones in regulating physiological functions in L. calcarifer. Therefore, as in the above mentioned fishes, possible roles of sGnRH should be clarified in L. calcarifer too.

Immunohistochemical localisation of cGnRH-II-ir cell bodies and fibers

The schematic illustration of cGnRH-II-ir cell bodies and fibers is summarised in Fig. 2b. cGnRH-II-ir cell bodies were localised only in the midbrain tegmentum, lying close to the medial longitudinal fascicle (nMLF) (Fig. 4 a). cGnRH-II-fibers were distributed in many areas from the $\mathrm{OB}$ of the anterior part to the caudal medulla oblongata of 


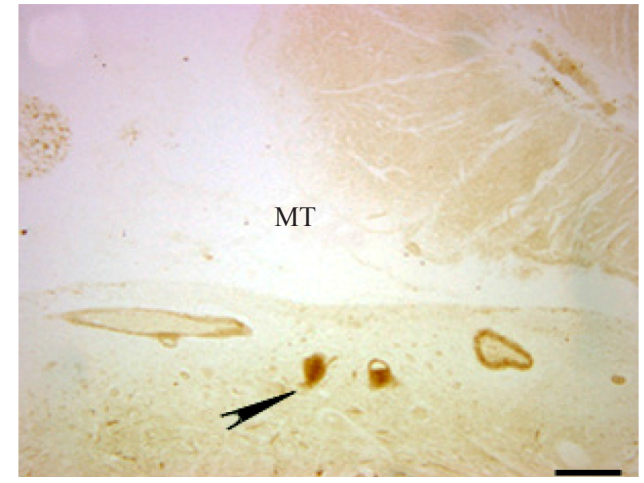

(a)

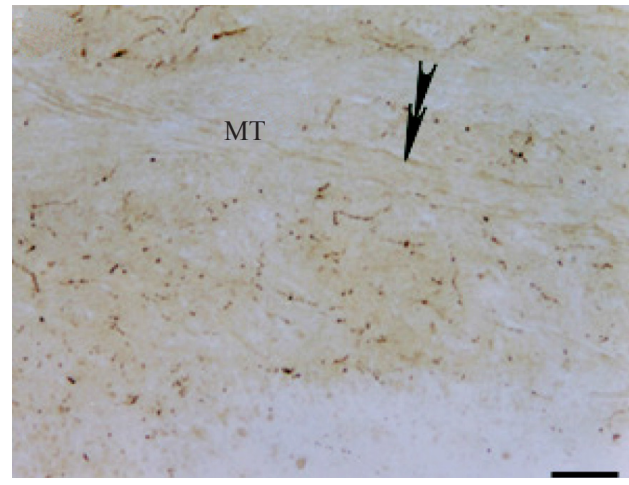

(b)

Fig. 4. Distribution of cGnRH-II- ir cell bodies (arrowhead) and fibers (double arrowhead) in sagittal sections. (a) cGnRH-II-ir cell bodies in the MT, (b) cGnRH-II-ir fibers in the midbrain. Bars, $100 \mu \mathrm{m}$

the posterior part of the brain. They were conspicuous in the OB, dorsal telecephalon, hypothalamus, optic tectum thalamus and medulla oblongata. Density of cGnRH-II-ir fibers was higher in the midbrain than in the other regions (Fig. 4b). In the cerebellum, few cGnRH-II-ir fibers were observed.

Localisation of cGnRH-II cells in the midbrain and distribution of fibers in many parts of the brain of L. calcarifer are consistent with those obtained from other fishes such as the masu salmon Oncorhynchus masou (Amano et al., 1991), V. moseri (Amano et al., 2002), D. labrax (Gonzalez-Martinez et al., 2001, 2002), P. olivaceus (Pham et al., 2007) and S. japonicus (Selvaraj et al., 2009). The widespread distribution of cGnRH-II-ir fibers within the central system in the brain of $L$. calcarifer also suggests a role of cGnRH-II in neuromodulation and or/neurotransmission as in the above-mentioned species. Moreover, the concentrated appearance of cGnRH-II fibers in the midbrain and hindbrain may also be involved in the auditory processing in the brain of this fish as found in damselfish Abudefduf abdominalis (Maruska and Tricas, 2011). Although cGnRH-II-ir fibers could be observed in the ventromedial hypothalamus, in the vicinity of the pituitary stalk, no cGnRH-II-ir fibers were detected in the pituitary of $L$. calcarifer. In addition, this hormone was undetectable in the pituitary. As such, these findings exclude the role of cGnRH-II in gonadotropic secretion in this species. However, cGnRH-II is the conservative form, suggesting complex roles in teleosts and vertebrates. For example, cGnRH-II is proposed to act as a regulator of pituitary function in $C$. auratus (Yu et al., 1988), European eel Anguilla anguilla (Dufour et al., 1993), tilapia Oreochromis mossambicus (Weber et al., 1997), and striped bass Morone saxatilis (Chow et al., 1998), or sexual behaviour in mammals, the marmoset Callithrix jacchus (Barnett et al., 2005) and food intake in the musk shrew Suncus murinus (Kauffman et al., 2005). On the other hand, in S. aurata (Zohar et al., 1995), African catfish Clarias gariepinus (Goos et al., 1997), and European seabass (Fornies et al., 2003), cGnRH-II has the potential to stimulate GTH secretion both in vivo and in vitro. It was also found that cGnRH-II in the pituitary increased during pubertal development, showing a role of cGnRH-II in regulation of gonadal development in the striped bass (Holland et al., 2001). In D. labrax, cGnRH-II is the modulator of pineal functions (Servili et al., 2010).

Immunohistochemical localisation of sbGnRH-ir cell bodies and fibers

The schematic illustration of sbGnRH-ir cell bodies and fibers is given in Fig. 2c. sbGnRH-ir cell bodies were detected only in the POA (Fig. 5b). These cell bodies were heavily labeled. sbGnRH-ir fibers were concentrated in the POA and were projected to the pituitary. A bundle of axons from the POA running towards the pituitary through the POA and hypothalamus was observed (Fig. 5c). In the pituitary, sbGnRH-ir fibers were profuse in the neurohypophysis and invaded the proximal pars distalis of adenohypophysis (Fig. 5c, d).

Distribution of sbGnRH cell bodies in L. calcarifer is similar to that in perciform and pleuronectiform fishes possessing three GnRH forms such as the $S$. aurata (Gothilf et al., 1996), red seabream Pagrus major (Senthilkumaran et al., 1999), D. labrax (GonzalezMartinez et al., 2002), V. moseri (Amano et al., 2002), P. olivaceus (Pham et al., 2007) and S. japonicus (Selvaraj et al., 2009), where sbGnRH-ir cells were expressed only in the POA. Results of the present study show that sbGnRH-ir fibers innervate the pituitary, and that sbGnRH level is dominant in the pituitary of the $L$. calcarifer. These results are in agreement with most studies conducted in the above mentioned species, which reveal the projection of the axonal sbGnRH fibers arising from the POA to the 


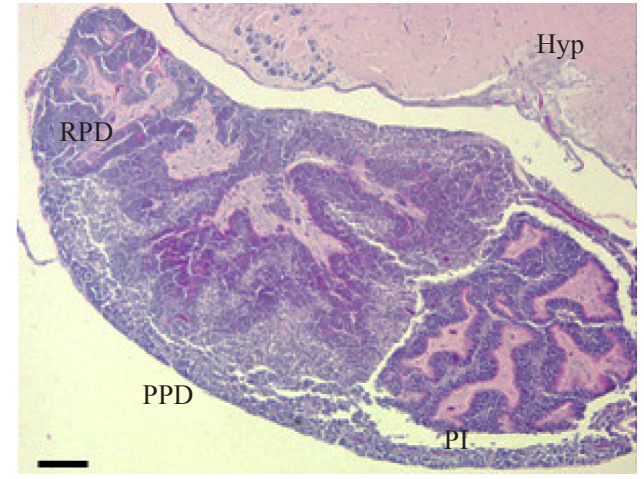

(a)

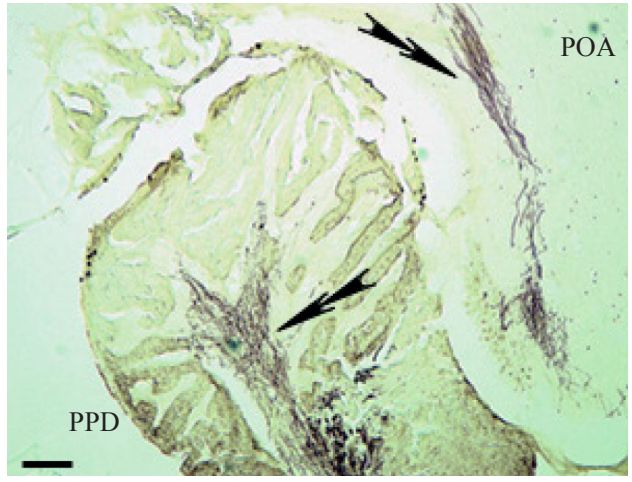

(c)

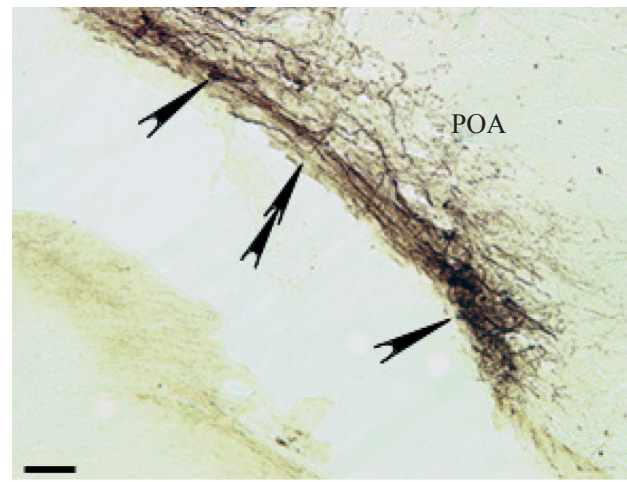

(b)

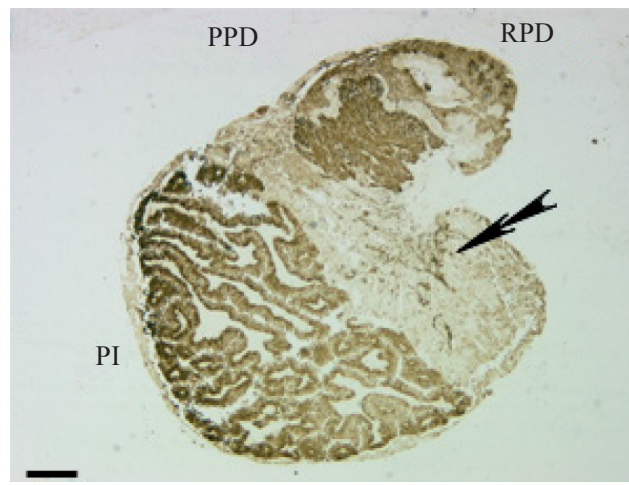

(d)

Fig. 5. Distribution of sbGnRH-ir cell bodies (arrowheads) and fibers (double arrowheads) in sagittal sections. (a) Cresyl violet stained section of the pituitary, RPD: rostral par distalis, PPD: proximal par distalis, PI: par intermedia, (b) Bundle of sbGnRH-ir fibers and sbGnRH-ir cell bodies in the POA, (c) Bundle of sbGnRH-ir fibers in the POA running toward the pituitary and sbGnRH-ir fibers in the PPD, (d) sbGnRH-ir fibers in the PPD of the pituitary. Bars, $100 \mu \mathrm{m}$

adenohypophysis, targeting the proximal pars distalis of the pituitary, and the major sbGnRH form in the pituitary. In addition, similar studies also showed that changes in the level of sbGnRH peptide and/or sbGnRH mRNA in the brains and pituitaries in these species were in accordance with ovarian development or seasonal reproductive activity. Moreover, it was demonstrated that sbGnRH cells in the POA were expressed simultaneously with the gonadal differentiation in association with maturation in O. mossambicus (Parhar, 1997), the cichlid Cichlasoma dimerus (Pandolfi et al., 2002) and S. aurata (Wong et al., 2004). All the findings suggest a role of sbGnRH in relation with reproduction by inducing gonadotropic secretion in teleosts. However, the role of sbGnRH and other GnRHs in reproductive physiology of the species should be verified by further investigations on change in GnRH peptide and/or the level of mRNA expression in the brain/pituitary during annual reproductive and spawning cycles. The origin of GnRH neuronal systems in $L$. calcarifer brain should be addressed by an ontogenic study to elucidate the precise roles of these GnRHs.

\section{Acknowledgements}

The authors express their gratitude to the Emeritus Professor K. Aida, University of Tokyo, for kindly providing lot 2 and Dr. K. Okuzawa, National Research Institute of Aquaculture, Japan for kindly providing acII6 and AS-691. This work was supported by the Grant Program of Basic Research in Natural Science, Project No. 106.10.83.09, NAFOSTED, Vietnam.

\section{References}

Adams, B. A., Vickers, E. D., Warby, C., Park, M., Fischer, W. H., Grey Craig, A., Rivier, J. E. and Sherwood, N. M. 2002. Three forms of gonadotropin-releasing hormone, including a novel form, in a basal salmonid, Coregonus clupeaformis. Biol. Reprod., 67: 232-239.

Almendras, J. M., Duenas, C., Nacario, J., Sherwood, N. M. and Crim, L. W. 1988. Sustained hormone release III. Use of gonadotropin releasing hormone analogues to induce multiple spawnings in seabass, Lates calcarifer. Aquaculture, 74: 97-111.

Amano, M., Oka, Y., Aida, K., Okumoto, N., Kawashima, S. and Hasegawa, Y. 1991. Immunocytochemical demonstration of salmon GnRH and chicken GnRH-II in the brain of 
masu salmon, Oncorhynchus masou. J. Comp. Neurol., 314: $587-597$

Amano, M., Oka, Y., Yamanome, T., Okuzawa, K. and Yamamori, K. 2002. Three GnRH systems in the brain and pituitary of a pleuronectiform fish, the barfin flounder, Verasper moseri. Cell Tissue Res., 309: 323-329.

Amano, M., Okumura, T., Okubo, K., Amiya, K., Takahashi, A. and Oka, Y. 2009. Biochemical analysis and immuno histochemical examination of a GnRH-like immunoreactive peptide in the central nervous system of a decapod crustacean, the kuruma prawn (Marsupenaeus japonicus). Zoo. Sci., 26: 840-845.

Amano, M., Urano, A. and Aida, K. 1997. Distribution and function of gonadotropin-releasing hormone $(\mathrm{GnRH})$ in the teleost brain. Zool. Sci., 14: 1-11.

Barnett, D. K., Bunnell, T. M., Millar, R. P. and Abbott, D. H. 2005. Gonadotropin-releasing hormone II stimulates female sexual behaviour in marmoset monkeys. Endocrinology, 1: 615-623.

Bogerd, J., Li, K. W., Janssen-Dommerholt, J. and Goos H. J. T. 1992. Two gonadotropin-releasing hormones from African catfish, Clarias gariepinus. Biochem. Biophys. Res. Commmun., 187: 127-134.

Carolsfeld, J., Powell, J. F., Park, M., Fischer, W. H., Craig, A. G., Chang, J. P., Rivier, J. E. and Sherwood, N. M. 2000. Primary structure and function of three gonadotropinreleasing hormones, including a novel form, from an ancient teleost, herring. Endocrinology, 141: 505-512.

Chow, M. M., Kight, K. E., Gothilf, Y., Alok, D., Stubblefield, J. and Zohar, Y. 1998. Multiple GnRHs present in a teleost species are encoded by separate genes: analysis of the sbGnRH and cGnRH-II genes from the striped bass, Morone saxatilis. J. Mol. Endocrinol., 21: 277-289.

Dufour, S., Montero, M., Le Belle, N., Bassompierre, M., King, J. A. and Millar, R. P. 1993. Differential distribution and response to experimental sexual maturation of two forms of gonadotropin-releasing hormone $(\mathrm{GnRH})$ in the European eel, Anguilla anguilla. Fish Physiol. Biochem., 11: $99-106$

Fornies, M. A., Carrillo, M., Mananos, E., Sorbera, L. A., Zohar, Y. and Zanuy, S. 2003. Relative potency of the forms of GnRH and their analogs on LH release in seabass. J. Fish Biol., 63: 73-89.

Garcia, L. B. 1989. Dose-dependent spawning response of mature female seabass, Lates calcarifer (Bloch), to pelleted luteinizing hormone releasing hormone analogue (LHRH - a). Aquaculture, 77: 85-96.

Gonzalez-Martinez, D., Madigou, T., Zmora, N., Anglade, I., Zanuy, S., Zohar, Y., Elizur, A., Munoz-Cueto, J. A. and Kah, O. 2001. Differential expression of three different prepro-GnRH (gonadotrophin-releasing hormone) messengers in the brain of the European seabass, Dicentrarchus labrax. J. Comp. Neurol., 429: 144-155.
Gonzalez-Martinez, D., Zmora, N., Mananos, E., Saligaut, D., Zanuy, S., Zohar, Y., Elizur, A., Kah, O. and Munoz-Cueto, J. A. 2002. Immunohistochemical localisation of three different prepro-GnRHs in the brain and pituitary of the European seabass, Dicentrarchus labrax, using antibodies to the corresponding GnRH-associated peptides. J. Comp. Neurol., 446: 95-113.

Goos, H. J. T., Bosma, P. T., Bogerd, J., Tensen, C. P., Li, K. W. Zandbergen, M. A. and Schulz, R. W. 1997. Gonadotropinreleasing hormones in the African catfish: molecular forms, localisation, potency and receptors. Fish Physiol. Biochem., 17: 45-51.

Gothilf, Y., Munoz-Cueto, J. A., Sagrillo, C. A., Selmanoff, M., Chen, T. T., Elizur, A., Kah, O. and Zohar, Y. 1996. Three forms of gonadotrophin-releasing hormone in a perciform fish (Sparus aurata): complementary deoxyribonucleic acid characterisation and brain localisation. Biol. Reprod., 55: 636-645.

Holland, M. C., Hassin, S. and Zohar, Y. 2001. Seasonal fluctuations in pituitary levels of the three forms of gonadotropin-releasing hormone in striped bass, Morone saxatilis (Teleostei), during juvenile and pubertal development. J. Endocrinol., 169: 527-538.

Kah, O., Lethimonier, C., Somoza, G., Guilgur, L. G., Vaillant, C. and Lareyre, J. J. 2007. GnRH and GnRH receptors in metazoan: a historical, comparative, and evolutive perspective. Gen. Comp. Endocrinol., 153: 346 -364.

Kauffman, A. S., Wills, A., Millar, R. P. and Rissman, E. F. 2005. Evidence that the type- 2 gonadotrophin-releasing hormone $(\mathrm{GnRH})$ receptor mediates the behavioural effects of GnRH-II on feeding and reproduction in musk shrews. J. Neuroendocrinol., 17: 489-497.

Kim, M. H., Oka, Y., Amano, M., Kobayashi, M., Okuzawa, K., Hasegawa, Y., Kawashima, S., Suzuki, Y. and Aida, K. 1995. Immunocytochemical localisation of sGnRH and cGnRH-II in the brain of goldfish, Carassius auratus. J. Comp. Neurol., 356: 72-82.

King, J. A. and Millar, R. P. 1979. Heterogeneity of vertebrate luteinising hormone-releasing hormone. Science, 206: 67-69.

Kobayashi, M.,Amano, M., Kim, M., Furukawa, K., Hasegawa, Y. and Aida, K. 1994. Gonadotropin-releasing hormones of terminal nerve origin are not essential to ovarian development and ovulation in goldfish. Gen. Comp. Endocrinol., 95: 192-200.

Lethimonier, C., Madigou, T., Munoz-Cueto, J. A., Lareyre, J. J. and Kah, O. 2004. Evolutionary aspects of GnRHs, GnRH neuronal systems and GnRH receptors in teleost fish. Gen. Comp. Endocrinol., 135: 1-16.

Marchant, T. A., Chang, J. P., Nahorniak, C. S. and Peter, R. E. 1989. Evidence that gonadotropin-releasing hormone also functions as a growth hormone-releasing factor in the goldfish. Endocrinology, 124: 2509-2518. 
Maruska, K. P. and Tricas, T. C. 2011. Gonadotropin-releasing hormone $(\mathrm{GnRH})$ modulates auditory processing in the fish brain. Horm. Behav., 59: 451-64.

Matsuo, H., Baba, Y., Nair, R. M. G., Arimura, A. and Schally, A. V. 1971. Structure of the porcine LH and FSH-releasing hormone I. The proposed amino acid sequence. Biochem. Biophys. Res. Commun., 43: 1334-1339.

Mohamed, J. S., Thomas, P. and Khan, I. A. 2005. Isolation, cloning, and expression of three prepro-GnRH mRNAs in Atlantic croaker brain and pituitary. J. Comp. Neurol., 488: 384-395.

Montaner, A. D., Park, M., Fischer, W. H, Craig, A. G., Chang, J. P., Somoza, G. M., Rivier, J. E. and Sherwood, N. M. 2001. Primary structure of a novel gonadotropin-releasing hormone in the brain of a teleost, pejerrey. Endocrinology, 142: $1453-1460$.

Moore, R. 1979. Natural sex inversion in the giant perch, Lates calcarifer. Aust. J. Mar. Freshw. Res., 30: 803-813.

Oka, Y. and Matsushima, T. 1993. Gonadotropin-releasing hormone $(\mathrm{GnRH})$ - immunoreactive terminal nerve cells have intrinsic rhythmicity and project widely in the brain. J. Neurosci., 13: 2161-2176.

Okuzawa, K., Amano, M., Aida, K., Hasegawa, Y., Tanaka, H. and Kagawa, H. 1993. Chromatographic and immunological identification of gonadotropin-releasing hormone in five marine teleosts. Fish Physiol. Biochem., 12: 337-345.

Okuzawa, K. and Kobayashi, M. 1999. Gonadotropin-releasing hormone neuronal systems in the teleostean brain and functional significance. In: Prasada, R. and Peter, R. E. (Eds.), Neural regulation in the vertebrate endocrine system. New York, Kluwer Academic, p. 85-100.

Pandolfi, M., Parhar, I. S., Ravaglia, M. A., Meijide, F. J., Maggese, M. C. and Paz, D. A. 2002. Ontogeny and distribution of gonadotropin-releasing hormone $(\mathrm{GnRH})$ neuronal systems in the brain of the cichlid fish, Cichlasoma dimerus. Anat. Embryol., 205: 271-281.

Parhar, I. S. 1997. GnRH in tilapia: three genes, three origins and their roles. In: Parhar, I. S. and Sakuma, Y. (Eds.), GnRH neurons: gene to behaviour. Tokyo, Brain Shuppan, p. 99-122.

Pham, K. X., Amano, M., Amiya, N., Kurita, Y., Shimizu, A. and Yamamori, K. 2007. Immunohistochemical localisation of three GnRH systems in brain and pituitary of Japanese flounder. Fish. Sci., 73: 1113-1122.

Phillips, M. J. 1998. Tropical mariculture and coastal environmental integrity. In: De Silva, S. S. (Ed.), Tropical mariculture. London, Academic Press, p. 17-69.

Powell, J. F. F., Zohar, Y., Elizur, A., Park, M., Fischer, W. H., Craig, A. G., Rivier, J. E., Lovejoy, D. A. and Sherwood, N. M. 1994. Three forms of gonadotropin-releasing hormone characterised from brains of one species. Proc. Natl. Acad. Sci. USA, 91: 12081-12085.
Rimmer, M. A. and Russell, D. J. 1998. Aspects of the biology and culture of Lates calcarifer. In: De Silva, S. S. (Ed.), Tropical Mariculture. London, Academic Press, p. 449-476.

Selvaraj, S., Kitano, H., Fujinaga, Y., Amano, M., Takahashi, A., Shimizu, A., Yoneda, M., Yamaguchi, A. and Matsuyama, M. 2009. Immunological characterisation and distribution of three GnRH forms in the brain and pituitary gland of chub mackerel, Scomber japonicus. Zool. Sci., 26: 828-839.

Senthilkumaran, B., Okuzawa, K., Gen, K., Ookura, T. and Kagawa, H. 1999. Distribution and seasonal variations in levels of three native GnRHs in the brain and pituitary of perciform fish. Neuroendocrinol., 11: 181-186.

Servili, A., Herrera-Perez, P., Kah, O. and Munoz-Cueto, J. A. 2012. The retina is a target for GnRH-3 system in the European seabass, Dicentrarchus labrax. Gen. Comp. Endocrinol., 175: 398-406.

Servili, A., Lethimonier, C., Lareyre, J. J., Lopez-Olmeda, J. F., Sanchez-Vazquez, F. J., Kah, O. and Munoz-Cueto, J. A. 2010. The highly conserved gonadotropin-releasing hormone-2 form acts as a melatonin-releasing factor in the pineal of a teleost fish, the European seabass, Dicentrarchus labrax. Endocrinology, 151: 2265-2275.

Sherwood, N. M., Eiden, L., Brownstein, M., Spiess, J., Rivier, J. and Vale, W. 1983. Characterisation of a teleost gonadotropin-releasing hormone. Proc. Natl. Acad. Sci. USA, 80: 2794-2798.

Soga, T., Ogawa, S., Millar, R. P., Sakuma and Y., Parhar, I. S. 2005. Localisation of the three GnRH types and GnRH receptors in the brain of a cichlid fish: insights into their neuroendocrine and neuromodulator functions. J. Comp. Neurol., 487: 28-41.

Stefano, A. V., Aldana-Marcos, H. J., Affani, J. M. and Somoza, G. M. 2000. Gonadotropin-releasing hormone $(\mathrm{GnRH})$ neuronal systems in the pejerrey, Odontesthes bonariensis (Atheriniformes). Fish Physiol. Biochem., 23: $215-223$.

Tan, S. L., Mohd-Adnan, A., Mohd-Yusof, N. Y., Forstner, M. R. J. and Wan, K. L. 2008. Identification and analysis of a prepro-chicken gonadotropin releasing hormone II (preprocGnRH-II) precursor in the Lates calcarifer, based on an EST-based assessment of its brain transcriptome. Gene, 441: 77-86.

Weber, G. M., Powell, J. F. F., Park, M., Fischer, W. H. and Craig, A. G. 1997. Evidence that gonadotropin-releasing hormone $(\mathrm{GnRH})$ functions as a prolactin releasing factor in a teleost fish, Oreochromis mossambicus and primary structure for three native GnRH molecules. J. Endocrinol., 155: 121-132.

White, S. A., Kasten, T. L., Bond, C. T., Adelman, J. P. and Fernald, R. D. 1995. Three gonadotropin-releasing hormone genes in one organism suggest novel roles for an ancient peptide. Proc. Natl. Acad. Sci. USA, 92: 8363-8367. 
Wong, T. T., Gothilf, Y., Zmora, N., Katherine, E. K., Meiri, I., Elizur, A. and Zohar, Y. 2004. Developmental expression of three forms of GnRH and ontogeny of the hypothalamuspituitary-gonadal axis in gilthead seabream, Sparus aurata. Biol. Reprod., 71: 1026-1035.

Yamamoto, N., Oka, Y., Amano, M., Aida, K., Hasegawa, Y. and Kawashima, S. 1995. Multiple gonadotropin-releasing hormone $(\mathrm{GnRH})$ immunoreactivity system in the brain of the dwarf gourami, Colisa lalia: immunohistochemistry and radioimmunoassay. J. Comp. Neurol., 355: 354-368.

Yamamoto, N., Oka, Y. and Kawashima, S. 1997. Lesions of gonadotropin-releasing hormone-immunoreactive terminal nerve cells: effects on the reproductive behaviour of male dwarf gouramis. Neuroendocrinol., 65: 403-412.

Yu, K. L., Sherwood, N. M. and Peter, R. E. 1998. Differential distribution of two molecular forms of gonadotropinreleasing hormone in discrete brain areas of goldfish, Carassius auratus. Peptides, 9: 625-630.

Zohar, Y., Elizur, A., Sherwood, N. M., Powell, J. F., Rivier, J. E. and Zmora, N. 1995. Gonadotropin-releasing activities of the three native forms of gonadotropin-releasing hormone present in the brain of gilthead seabream, Sparus aurata. Gen. Comp. Endocrinol., 97: 289-299. 